Original Article

\title{
EFFICIENCY OF CURCUMIN AND CHITOSAN NANOPARTICLES AGAINST TOXICITY OF POTASSIUM DICHROMATE IN MALE MICE
}

\author{
NOURA RADY MOHAMED ${ }^{a^{*}}$, THANAA MOSTAFA BADR ${ }^{a}$, MOHAMED R. ELNAGAR \\ aDepartment of Zoology, Women's Collage, Ain Shams University, Cairo, Egypt, bDepartment of Pharmacology and Toxicology, Faculty of \\ Pharmacy, Al-Azhar University, Cairo, Egypt \\ *Email: noura_rady@yahoo.com
}

Received: 11 Nov 2020, Revised and Accepted: 23 Dec 2020

\section{ABSTRACT}

Objective: The purpose of this work is to examine the protective effect of nanocurcumin and nanochitosan supplementation against potassium dichromate toxicity in male mice.

Methods: Male albino mice weighing 25-30 gm were divided into six groups; the first group received saline. Second and third groups were given oral dose of nanocurcumin and nanochitosan respectively for $5 \mathrm{~d}$. Fourth group was injected subcutaneously with a single dose of potassium dichromate for $24 \mathrm{~h}$. Group five and six were administrated nanocurcumin and nanochitosan, respectively prior to potassium dichromate. Animals were anesthetized by ether anesthesia then bone marrow was harvested for chromosomal examination and epididymal sperms were collected for sperm morphology, while Kidneys and testes were collected for western blot and biochemical analysis.

Results: Potassium dichromate induced significant $(\mathrm{P} \leq 0.05)$ increase in chromosome and sperm abnormalities as well as testicular and renal MDA, renal MPO, renal contents of IL-18 and IGF-1, testicular contents of caspase 3 and cytosolic cytochrome c, a reduction in testosterone level, and GPx of renal and testicular tissues compared to control group. Pretreatment with both types of nanoparticles showed significant $(\mathrm{P} \leq 0.05)$ mitigation against most alterations induced by potassium dichromate; moreover, nanochitosan gave more significant $(\mathrm{P} \leq 0.05)$ improvement against chromosome and sperm abnormalities than nanocurcumin.

Conclusion: The present study revealed that the selected nanoparticles have antioxidant as well as antigenotoxic properties against toxicity of potassium dichromate.

Keywords: Potassium dichromate genotoxicity, Nanochitosan, Nanocurcumin, Nephrotoxicity, Testicular damage

(c) 2021 The Authors. Published by Innovare Academic Sciences Pvt Ltd. This is an open access article under the CC BY license (https://creativecommons.org/licenses/by/4.0/) DOI: https://dx.doi.org/10.22159/ijpps.2021v13i2.40224. Journal homepage: https://innovareacademics.in/journals/index.php/ijpps.

\section{INTRODUCTION}

Widespread pollution by heavy metals has critical consequences on the global public health associated with the quality of the environment and able to induce toxicity even at low level of exposure [1-4]. Among those toxic heavy metals, chromium is an inorganic environmental pollutant which still widely used in many modern industries. It commonly enters the environment through the release from these industries into soil and water, causing environmental pollutions [5-7].

Hexavalent chromium compounds, such as potassium dichromate (PDC), is very highly poisonous substance and can induce multiple organ toxicity, like nephrotoxicity $[8,9]$, testicular toxicity $[10,11]$ with negative effects on fertilization [12], aberrations in bone marrow and spermatocytes [13], as well as reduced motility of live sperm, and sperm death [14]. It can also produce injuries in other organs, including liver [15], brain [16], and heart [17]. Many studies have been conducted to explore the mechanisms of PDC toxicity on multiple aspects, including increased production of reactive oxygen species (ROS) [15, 18, 19], inflammation [20], oxidative DNA damage/ apoptotic changes [16, 21, 22], genotoxicity/mutagenicity [23, 24], and eventually inducing cell damage and death [19].

Recently, it has been focused on the beneficial role and protective effect of phytochemicals on oxidative Stress-mediated testicular toxicity and kidney injury $[25,26]$. Curcumin (CUR) is main active compound in the plant Curcuma longa with several biological activities $[27,28]$. It has a protective action against several organs' toxicities [29-31]. The pharmacological effects of CUR could attribute to antiinflammatory [30,32], antioxidant [33, 34], anticancer [35] activities. Despite numerous therapeutic effects, the bioavailability of CUR is relatively low with poor intestinal absorption and aqueous solubility, rapid metabolism in the liver and systemic elimination [36-38]. Therefore, the nanoformulations of CUR is the most effective tool to enhance the water solubility, thereby improving its dispersibility, absorption and bioavailability $[39,40]$.

Chitosan (CHI) is a modified natural carbohydrate polymer prepared by partial N-deacetylation of chitin and popularly used for drug delivery formulations. CHI nanoparticles-dependent formulations have gained widespread interest as nanoparticles in pharmaceutical drug delivery $[41,42]$, it provides a simple method of preparation and for their use in nutritional supplements and nanomedicine applications $[41,43]$ with better stability, low toxicity profile, and the reliability to be used as a food ingredient [44]. CHI has an enormous economic and medicinal values because of its biological properties. The benefit of CHI with respect to its intrinsic antioxidant $[45,46]$, antimutagenicity [47], anti-inflammatory [48] properties have been reported. However, as in CUR, the nanoparticle of CHI is more have attracted the attention of researchers from different research areas [46, 49].

In view of the oxidative stress has been associated with PDC-induced pathogenesis in numerous organs, the pharmacological use of antioxidant supplements as adjuvant therapy could slow or inhibit the oxidation by toxic molecules and can be important for cell homeostasis. With nanotechnology importance in the improvement of the drug physicochemical properties and bioavailability, the main aim of the present study was to investigate the protective effect of nano CHI and nano CUR particles against the PDC induced toxicity in the adult male mice.

\section{MATERIALS AND METHODS}

\section{Chemicals}

Potassium dichromate was purchased from Sigma chemical company (St. Louis, MO). Curcumin and chitosan nanoparticles were both prepared by NanoTech Egypt Company for Photo-Electronics (Giza, Egypt), and both were characterized by TEM technique (fig. 1). 


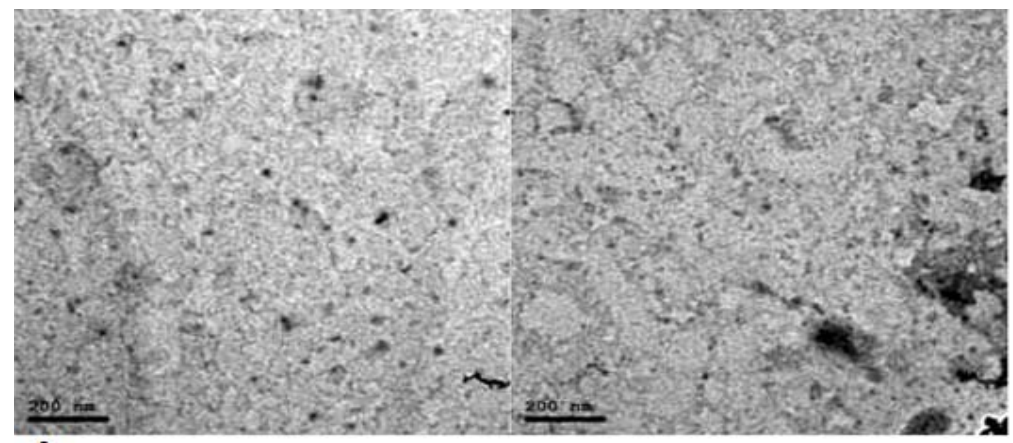

A

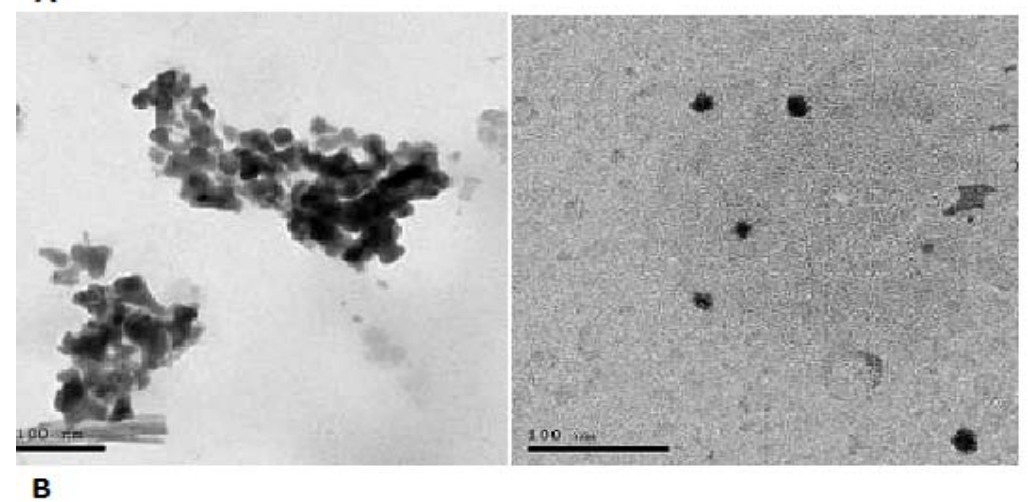

Fig. 1: TEM characterization of nanoparticles. (A) Shows size and shape of curcumin $(30 \pm 5 \mathrm{~nm})$, and (B) Shows size and shape of chitosan $(20 \pm 5 \mathrm{~nm})$

\begin{abstract}
Animals
Experiments were performed on thirty six adult male mice (Mus musculus), weighing 25-30 gm, were obtained from the Animal House Colony of the National Research Centre, Cairo, Egypt and housed in polypropylene cages in a temperature-controlled room $\left(25 \pm 1^{\circ} \mathrm{C}\right)$ under a $12: 12$ hour light-dark cycle, a relative humidity of $60 \pm 5 \%$ and free access to tap water and standard rodent chow with the approval of the Ethics Committee of the National Research Centre (FWA 00014747) that follows the recommendations of the National Institutes of Health Guide for Care and Use of Laboratory Animals (publication No. 85-23, revised in 1985). After $2 \mathrm{w}$ of acclimation, animals were divided into six groups of six mice each.
\end{abstract}

\section{Experimental design}

Group I (control) mice received saline only, while mice in group II (CUR) and III (CHI) were treated with $60 \mathrm{mg} / \mathrm{Kg}$, oral dose of nanocurcumin and nanochitosan alone, respectively, for 5 consecutive days [50]. Group IV (PDC) mice were given subcutaneous (s. c) injection of potassium dichromate as a single dose (15 mg/kg/bw) for $24 \mathrm{~h}$ [51]. In group V (CUR+PDC) mice were given nanocurcumin first before injected with potassium dichromate. Mice in group VI (CHI+PDC) were given nanochitosan first before injected with potassium dichromate. At the end of the experiment, animals were sacrificed under anesthesia by diethyl ether and bone marrow, sperms as well as kidneys and testes were separated for the following analysis.

\section{Chromosomal aberration (CA) assay}

Metaphase chromosomal analysis were performed according to Preston et al. [52]. In brief, each mouse 90 min before sacrifice was injected intraperitoneally with colchicine $(0.04 \%, 0.1 \mathrm{ml} / 20 \mathrm{~g}$ b.w. $)$. Bone marrow cells were extracted from femur bones and incubated for $20 \mathrm{~min}$ at $37{ }^{\circ} \mathrm{C}$ in $0.56 \% \mathrm{KCl}$ hypotonic solution. After centrifugation at $1000 \mathrm{rpm}$ for $10 \mathrm{~min}$, cells were collected and fixed three times in a freshly prepared solution of methanol: glacial acetic acid $(3: 1, v / v)$. The cells were dropped on cold slides then stained with Giemsa stain for $10 \mathrm{~min}$ after it dried. A total of 300 well-spread metaphase plates were scored for CA per each group using light microscope at a magnification of $1000_{x}$.

\section{Sperm morphology}

The sperm morphology was evaluated by analysis of sperm smears made from cauda epididymis. The prepared slides were fixed in absolute methyl alcohol for $15 \mathrm{~min}$ then stained with Giemsa stain for $10 \mathrm{~min}$. A thousand sperm cells per mouse were assessed for morphological abnormalities under oil immersion at 1000x, and were classified into three general categories: head, tail, as well as head and tail abnormalities [53].

\section{Preparation of tissue homogenates and protein quantification}

Specimens from kidney and testis were divided into three parts. The individual piece was separately weighted and homogenized gently with a Potter-Elvenhjem tissue grinder. One part was lysed in [50 mmol phosphate buffer saline (PBS); $\mathrm{pH}$ 7.4] for estimation of protein content, testosterone level and MPO activity. The second piece was homogenized in $[10 \mathrm{mmol}$ potassium phosphate buffer; pH 7.4] for estimation of MDA levels and GPx activity, and the third part was used for the Western blotting analysis. The crude kidney and testicular homogenates were centrifuged at $10,000 \mathrm{rpm}$ for 10 min at $4{ }^{\circ} \mathrm{C}$, and the resultant supernatant was used for the specific assay. Protein content in tissue homogenate was measured according to the method Bradford [54], with bovine serum albumin (BSA) solution as standard.

\section{Testosterone levels}

Testosterone levels in the testis of mice [55], with specimens, standards, and controls (in triplicates) were prepared to manufacturer's instructions by the testosterone HRP-dependent immunoassay kit (BioVision Research Products, USA). The absorbance was measured at $405 \mathrm{~nm}$ on Multiskan ${ }^{\circledR} \mathrm{EX}$ microplate reader (Thermo Scientific, USA).

\section{Oxidative stress status}

\section{Malondialdehyde (MDA) assay}

The tissue lipid peroxidation (LPO) products were evaluated by thiobarbituric acid (TBA) reactive substances (TBARS) in the kidney and testis tissues, with the $1,1^{\prime}, 3,3^{\prime}$-tetramethoxypropane was used as a standard in constructing the calibration curve [56]. In short, the 
samples were diluted and proceeded for the acidic reaction while heating. After incubation, $2 \mathrm{ml}$ of $\mathrm{n}$-butanol was added to extract the resultant pink color. The concentrations of TBA-MDA adducts in samples was measured at 535 and $520 \mathrm{~nm}$ using spectrophotometer (Jenway 6305 UV/VIS, UK).

\section{Glutathione peroxidase (GPx) activity}

The kidney and testicular GPx activities were measured in the tissue homogenates prepared in phosphate buffer using the commercially available GPx kit (Biodiagnostic, Egypt) according to the manufacturer's instructions [57]. The changes in absorbance per min were measured at $340 \mathrm{~nm}$ using spectrophotometer (Jenway 6305 UV/VIS, UK) against the deionized water as a blank, and the GPx activity was expressed at $\mathrm{U} / \mathrm{mg}$ protein.

\section{Myeloperoxidase (MPO) activity}

The MPO activity in kidney was assessed using a procedure like that recorded previously [58]. In short, homogenized samples [in 50 mmol phosphate buffer saline, PBS; $\mathrm{pH}$ 7.4] were centrifuged for 10 min at $15000 \mathrm{rpm}$, and the pellets were then suspended in $50 \mathrm{mmol}$ PBS containing $0.5 \%$ hexadecyl trimethyl ammonium bromide (HETAB). The samples were then mixed, sonicated, and centrifuged at $15000 \mathrm{rpm}$ for $10 \mathrm{~min}$ before adding to the reaction mixture containing $50 \mathrm{mmol}$ PBS, $20 \mathrm{mmol} \mathrm{H}_{2} \mathrm{O}_{2}$, and o-dianisidine. The activity of MPO was expressed as $\mathrm{U} / \mathrm{mg}$ protein, where one unit of MPO activity was defined as the amount of the enzyme in samples that produced a change in absorbance measured at $460 \mathrm{~nm}$ for 3 $\min$.

\section{Western blot}

The Western analysis was performed according to previous methods $[59,60]$. The tissues from kidney and testis were homogenized with lysis solution [10 mmol Tris base, $25 \mathrm{mmol}$ ethylene glycol-bis( $\beta$ aminoethyl ether)- $\mathrm{N}, \mathrm{N}, \mathrm{N}^{\prime}, \mathrm{N}^{\prime}$-tetraacetic acid (EGTA), $25 \mathrm{mmol}$ ethylenediaminetetraacetic acid (EDTA), $100 \mathrm{mmol} \mathrm{NaCl}, 1.5 \%$ (v/v) Nonidet P-40 (NP-40), and 1.5\% (v/v) Triton X-100; pH 7.4] supplemented with 1:500 protease inhibitors, and phosphatase inhibitors cocktails (Sigma). Aliquots of the kidney and testicular homogenates containing $40 \mu \mathrm{g}$ proteins were mixed and boiled for 5 min with $4 x$ sample Loading buffer [12\% Sodium Dodecyl Sulphate (SDS), $700 \mathrm{mmol}$ Tris-HCl, $600 \mathrm{mmol}$ dithiothreitol (DTT), 60\% glycerol, and $0.02 \%$ Bromophenol blue; $\mathrm{pH}$ 6.8], and allowed to cool on ice for $5 \mathrm{~min}$ before subjected to 12\% SDS-PAGE. The separated proteins were transferred electrophoretically from the gels onto polyvinylidene fluoride (PVDF) membranes using the Trans-Blot® SD semi-dry transfer cell (Biorad, USA). Then, the membranes were blocked at RT in TBS buffer [50 mmol Tris-Cl, and $150 \mathrm{mmol} \mathrm{NaCl}$; $\mathrm{pH}$ 7.4] containing 5\% nonfat dry milk (Biorad) for $2 \mathrm{~h}$ and immediately probed for IL-18 (1:1000 dilution), IGF-1 (1:400 dilution), cytochrome $c$ (1:300 dilution), caspase-3 (1:250 dilution), or $\beta$-Actin (1:2000 dilution) at $23-25^{\circ} \mathrm{C}$ for $16-18 \mathrm{~h}$. After that, the membranes were washed in TBS-T [50 mmol Tris-Cl, and $150 \mathrm{mmol}$ $\mathrm{NaCl}, 0.15 \%$ Tween-20; $\mathrm{pH} 7.4$ ] for $3 \times 10 \mathrm{~min}$ and incubated with their corresponding HRP-conjugated secondary antibody for $2 \mathrm{~h}$ at RT. Then, the membranes were washed 3X10 min in TBST and exposed to the chemiluminescence Western Lightning ECL (Perkin Elmer, Waltham, MA) for $1 \mathrm{~min}$. Blots were visualized in Chemi-Doc imager (Biorad), and the bands intensities were then measured with normalization the $\beta$-Actin, as an internal reference control.

\section{Statistical analysis}

All data in this study are presented as mean \pm SD values. GraphPad Prism version 7 for Windows (GraphPad Software, San Diego, CA, USA) was used for performing statistical analysis. Data were analyzed using one-way analysis of variance (ANOVA) with Tukey's multiple comparisons test. The difference between groups was considered statistically significant when $\mathrm{P} \leq 0.05$.

\section{RESULTS}

\section{Chromosomal aberration assay}

Potassium dichromate (PDC) induced high significant level of chromosomal aberrations after one day of induction and the frequency of total chromosomal abnormalities was $47 \%$ compared to control $11.7 \%$ (table 1 ).

Table 1: Number and percentage of structural and numerical chromosomal aberrations in mice bone marrow cells of treated groups. Fifty metaphases were examined in each mouse; totally 300 metaphases examined per group

\begin{tabular}{|c|c|c|c|c|c|c|c|c|c|c|c|c|c|c|c|c|c|}
\hline \multirow[t]{2}{*}{ Groups } & \multicolumn{10}{|c|}{ Structural chromosomal aberration (SCA) } & \multicolumn{3}{|c|}{$\begin{array}{l}\text { Numerical } \\
\text { chromosomal } \\
\text { aberration (NCA) }\end{array}$} & \multirow[t]{2}{*}{$\begin{array}{l}\text { Total } \\
\text { SCA (no } \\
\text { and \%) }\end{array}$} & \multirow{2}{*}{$\begin{array}{l}\text { Total } \\
\text { NCA } \\
\text { (no } \\
\text { and \%) }\end{array}$} & \multirow{2}{*}{$\begin{array}{l}\text { Total } \\
\text { SCA } \\
\text { and } \\
\text { NCA }\end{array}$} & \multirow[t]{2}{*}{ mean \pm SE } \\
\hline & $\mathrm{Br}$ & G & Del & $\mathbf{R}$ & $\begin{array}{l}\text { C. } \\
\text { S }\end{array}$ & Iso & Dir. & Cf & Pulv & dic & Нypo & Hyper & Poly & & & & \\
\hline Control & 2 & 3 & 6 & 0 & 8 & 1 & 2 & 6 & 0 & 1 & 6 & 0 & 0 & 299.7 & 62 & 3511.7 & $5.83 \pm 1.17$ \\
\hline CUR & 4 & 2 & 7 & 1 & 6 & 2 & 4 & 4 & 0 & 2 & 4 & 0 & 0 & 3210.67 & 40.67 & 3612 & $6 \pm 1.41$ \\
\hline $\mathrm{CHI}$ & 3 & 1 & 5 & 1 & 7 & 0 & 3 & 5 & 0 & 0 & 3 & 1 & 0 & 258.33 & 40.67 & 299.7 & $4.83 \pm 1.94$ \\
\hline PDC & 11 & 9 & 20 & 6 & 10 & 5 & 9 & 11 & 12 & 8 & 29 & 8 & 3 & 10133.67 & 4013.33 & 14147 & $23.5 \pm 1.87^{*}$ \\
\hline CUR+PDC & 7 & 6 & 15 & 4 & 7 & 4 & 8 & 10 & 7 & 5 & 10 & 4 & 0 & 7324.33 & 144.67 & 8729 & $14.5 \pm 1.52^{* \# \$}$ \\
\hline $\mathrm{CHI}+\mathrm{PDC}$ & 5 & 3 & 11 & 3 & 7 & 3 & 7 & 5 & 4 & 4 & 8 & 2 & 1 & 5217.33 & 113.67 & 6321 & $10.5 \pm 2.59$ *\#\$ \\
\hline
\end{tabular}

Data are expressed as mean \pm SD Statistical analysis was performed for statistical changes between the selected groups: ${ }^{*} \mathrm{P} \leq 0.05$ indicates statistical difference from the vehicle-treated (control) group, ${ }^{*} \mathrm{P} \leq 0.05$ indicates statistical difference from the PDC -treated group, and $\$ \mathrm{P} \leq 0.05$ indicates statistical difference between CHI+PDC and CUR+PDC groups in one-way ANOVA test with Tukey's multiple comparisons test. Abbreviations: $\mathrm{br}=\mathrm{break}, \mathrm{g}=\mathrm{gap}$, del=deletion, $\mathrm{r}=\mathrm{ring}, \mathrm{cs}=$ centric separation, iso= isochromatid-gap, dir=diradial, Cf=centric fusion, Pulv=pulverization, dic=dicentric, Hypo=hypoploidy, Hyper=hyperploidy, Poly=polyploidy.

The different detected types of structural chromosomal aberrations were deletion, pulverization, break, centric-fusion, centricseparation, gap, diradial, dicentric, ring and iso-gap. Moreover, the most numerical chromosomal aberrations were in the form of hypoploidy (fig. 2A). Curcumin (CUR) or chitosan (CHI) nanoparticles does not induced significant difference as compared to control group. Pre-treatments with nano CUR or nano CHI before PDC injection showed significant reduction in the percentage of total chromosomal aberrations. It was noticed that pre-treatment with nano $\mathrm{CHI}$ gave best results and reduced the chromosomal aberrations (21\%) significantly compared to nano CUR (29\%), fig. $2 \mathrm{~B}$.

\section{Sperm morphology assay}

Examination of sperms prepared from the control group revealed 5701 sperm are normal and the remaining sperms (299) were deformed. Among these deformed forms are sperms with hook deformation, amorphous, big head and abnormal tail, was more prevalent. Other types of abnormalities were recorded in rather low frequency (table 2). 

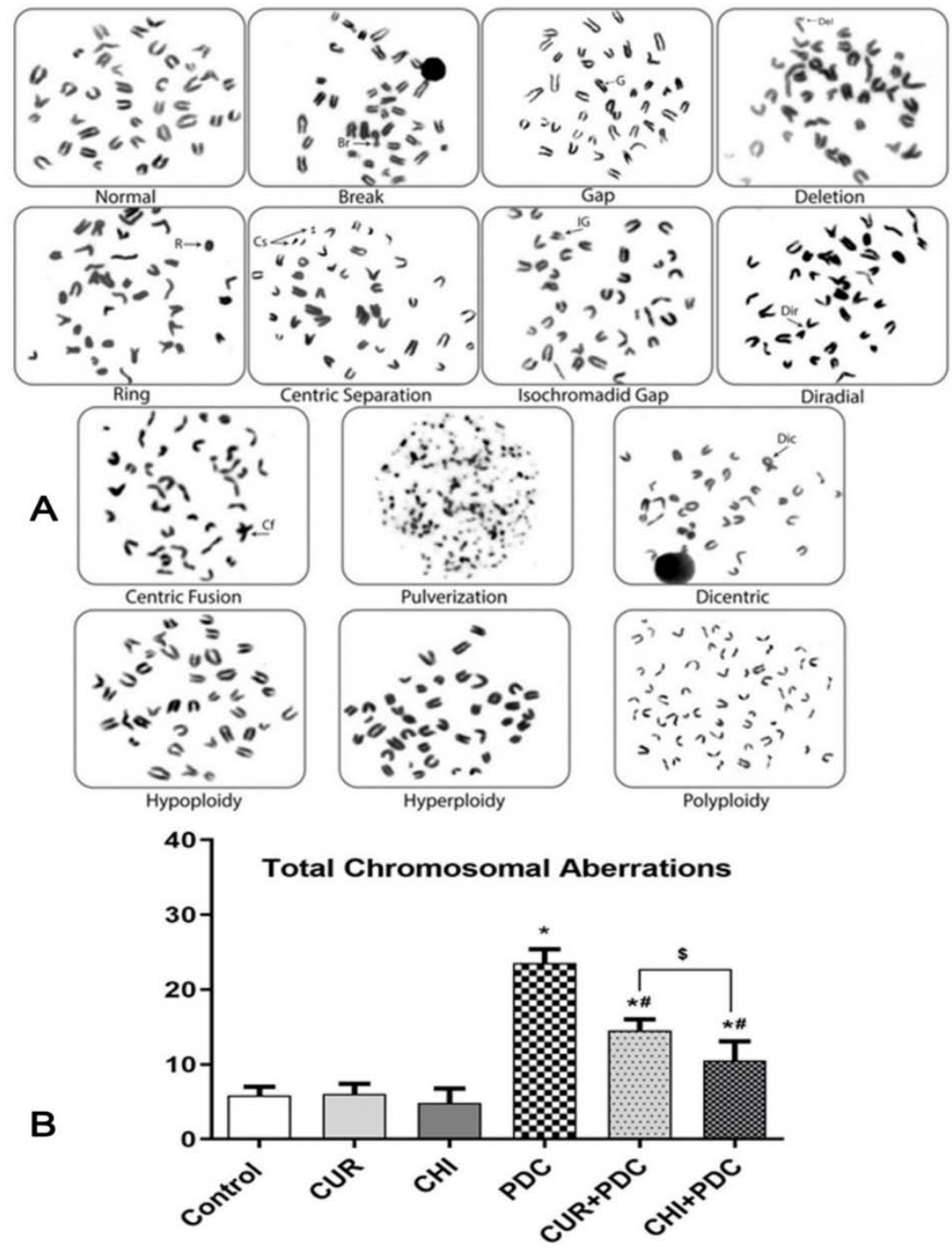

Fig. 2: Chromosomal aberration test. (A) Normal metaphase and different structural and numerical chromosomal aberrations in mice bone marrow from metaphases of treated groups. (B) Number of total chromosomal aberrations in the control and treated groups ( $\mathrm{n}=6$ ). Data are expressed as mean \pm SD Statistical analysis was performed for statistical changes between the selected groups: ${ }^{*} \mathrm{P} \leq 0.05$ indicates statistical difference from the vehicle-treated (control) group, $\mathrm{P} P \leq \mathbf{0 . 0 5}$ indicates statistical difference from the PDC-treated group, and \$P $\leq 0.05$ indicates statistical difference between CHI+PDC and CUR+PDC groups in one-way ANOVA test with Tukey's multiple comparisons

test. Abbreviations: CUR, rats treated with nanocurcumin; CHI, rats treated with nanochitosan; PDC, rats treated with potassium dichromate; CUR-PDC, rats treated nanocurcumin before potassium dichromate and; CHI-PDC, rats treated with nanochitosan before potassium dichromate

Table 2: Number and percentage of sperm morphology abnormalities in of treated groups, one thousand sperm was examined in each animal, totally six thousand sperm examined per group

\begin{tabular}{|c|c|c|c|c|c|c|c|c|c|c|c|c|c|c|}
\hline \multirow[t]{2}{*}{ Groups } & \multirow{2}{*}{$\begin{array}{l}\text { Normal } \\
\text { sperms }\end{array}$} & \multicolumn{7}{|c|}{ Head abnormalities } & \multirow{2}{*}{$\begin{array}{l}\text { Total } \\
\text { head } \\
\text { abnor. }\end{array}$} & \multirow{2}{*}{$\begin{array}{l}\text { Tail } \\
\text { abnor. }\end{array}$} & \multirow{2}{*}{$\begin{array}{l}\text { Headand } \\
\text { Tail } \\
\text { abnor. }\end{array}$} & \multicolumn{3}{|c|}{ Total abnormalities } \\
\hline & & hd & amr & bh & sh & tri & $2 \mathbf{h}$ & col & & & & $\begin{array}{l}\text { Total } \\
\text { abnor. }\end{array}$ & $\begin{array}{l}\text { Mean } \\
\pm \text { SD }\end{array}$ & $\%$ \\
\hline Control & 5701 & 82 & 47 & 33 & 20 & 15 & 12 & 7 & 216 & 66 & 17 & 299 & $\begin{array}{l}49.83 \pm \\
7.25\end{array}$ & 4.98 \\
\hline CUR & 5645 & 119 & 65 & 39 & 30 & 27 & 13 & 6 & 299 & 52 & 4 & 355 & $\begin{array}{l}59.17 \pm \\
2.86^{*}\end{array}$ & 5.92 \\
\hline $\mathrm{CHI}$ & 5694 & 109 & 77 & 40 & 27 & 19 & 10 & 9 & 291 & 14 & 1 & 306 & $51 \pm 2.61$ & 5.1 \\
\hline PDC & 4208 & 694 & 179 & 78 & 52 & 40 & 35 & 11 & 1089 & 620 & 83 & 1792 & $\begin{array}{l}298.67 \pm \\
7.26^{*}\end{array}$ & 29.87 \\
\hline CUR+PDC & 5070 & 367 & 155 & 81 & 50 & 65 & 29 & 12 & 759 & 138 & 33 & 930 & $155 \pm 3.74^{* \# \$}$ & 15.5 \\
\hline $\mathrm{CHI}+\mathrm{PDC}$ & 5292 & 283 & 129 & 66 & 39 & 46 & 27 & 8 & 598 & 96 & 14 & 708 & $118 \pm 4.52^{* \# \$}$ & 11.8 \\
\hline
\end{tabular}

Data are expressed as mean \pm SD Statistical analysis was performed for statistical changes between the selected groups: ${ }^{*} \mathrm{P} \leq 0.05$ indicates statistical difference from the vehicle-treated (control) group, ${ }^{*} \mathrm{P} \leq 0.05$ indicates statistical difference from the PDC-treated group, and $\$ \mathrm{P} \leq 0.05$ indicates statistical difference between CHI+PDC and CUR+PDC groups in one-way ANOVA test with Tukey's multiple comparisons test. Abbreviations: hd= hook deformation, amr= amorphous, bh= big head, $\mathrm{sh}=$ small head, tri= triangular, $2 \mathrm{~h}=$ two heads, col= collapsed, abnor= abnormalities. 
There was no significant difference between CHI group and control group; meanwhile, a significant difference was observed in CUR group compared to the control group. Treatment with PDC resulted in significant increase in the incidence of sperm shape abnormalities. Data revealed that 1792 of the examined spermatozoa were damaged. Hook deformation was the most frequent type of head abnormalities which involved three types: acute curvature (the anterior tip of the sperm was acutely curved); deformed orientation (the anterior tip of the sperm was abnormally straight and showing less curvature); hookless (the lack of the anterior tip), fig. 3A.

The remaining types of head abnormalities could be arranged in descending manner as follows: Amorphous head (irregular outline head that does not fit with any particular shape). Bighead (normal outline head with markedly bigger size than normal). Small head (normal outline head with a markedly smaller size than normal). Triangle head (head has three sides without hook). Two heads and collapsed head (curved down) were found to be less frequent. In normal conditions, the tail is long attached to the head at the base and extends with a continuous decreased in diameter. Meanwhile, after administration of PDC many deformities were seen in the form of forked tail, thin tail, and coiled tail. On the other hand, oral administration of nanoparticles of CUR or CHI before PDC significantly decreased the frequency of total sperm abnormalities (15.5\% and 11.8\%, respectively) compared with the PDC group (29.87\%). The pre-treatment with CHI nanoparticles decreased total sperm abnormalities significantly compared to CUR nanoparticles (fig. 3B).

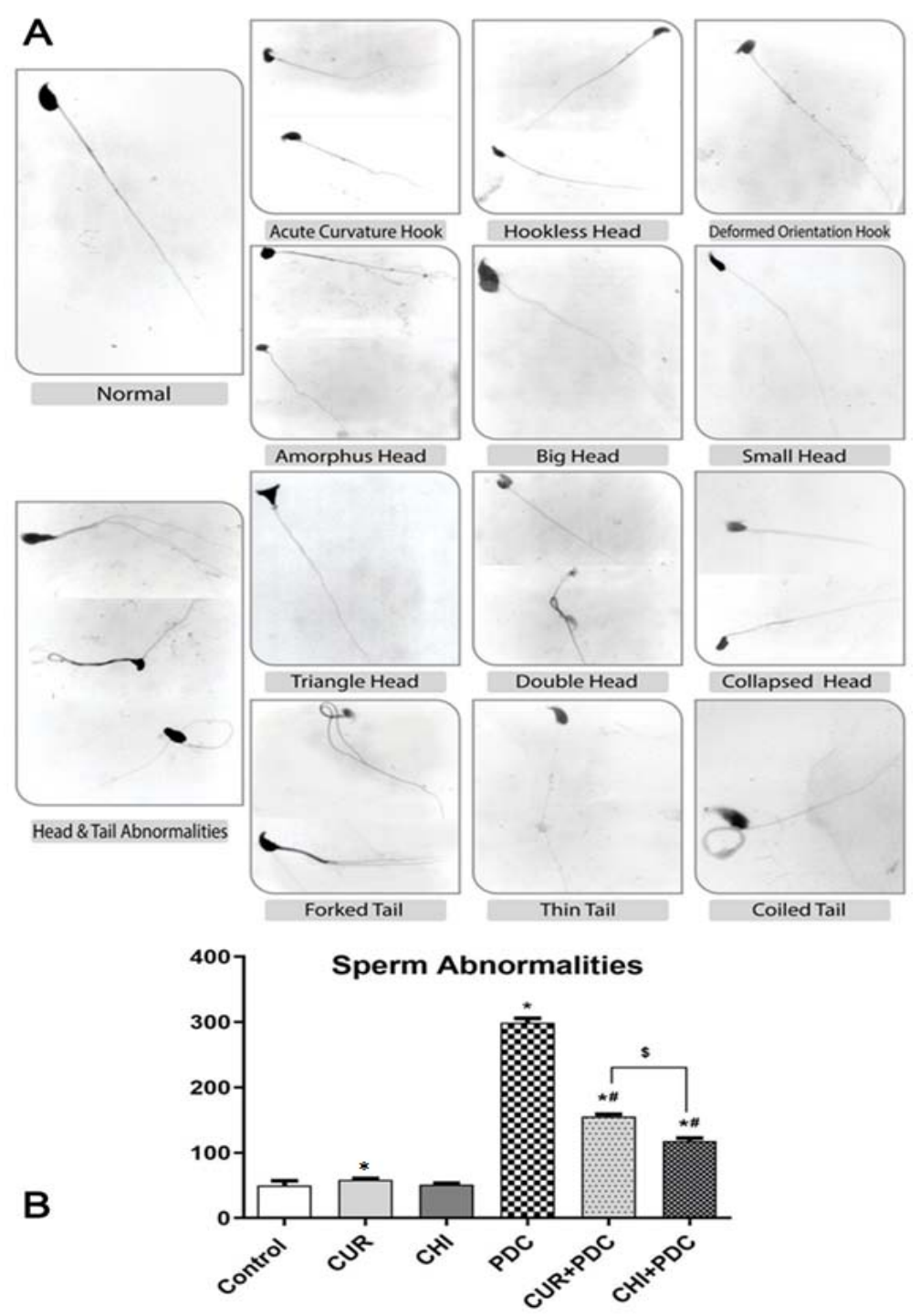

Fig. 3: Sperm morphology (A) Normal spermatozoa and different abnormalities in head, tail, or head and tail from treated groups. (B) Number of total abnormalities in the control and treated groups $(n=6)$. Data are expressed as mean \pm SD Statistical analysis was performed for statistical changes between the selected groups: ${ }^{*} \mathrm{P} \leq \mathbf{0 . 0 5}$ indicates statistical difference from the vehicle-treated (control) group, ${ }^{\# P} \leq$ 0.05 indicates the statistical difference from the PDC-treated group, and ${ }^{\mathrm{P}} \mathrm{P} \leq 0.05$ indicates statistical difference between $\mathrm{CHI}+\mathrm{PDC}$ and CUR+PDC groups in one-way ANOVA test with Tukey's multiple comparisons test

\section{Oxidative stress markers}

Normal levels of oxidative stress biomarkers were observed in the control group and in groups treated with CHI as well as CUR nanoparticles. On the other hand, renal and testicular GPx content was significantly reduced ( $61.4 \%$ and $50.7 \%$, respectively) following
PDC-administration, and a significant elevation of MDA content was detected in the kidney (47.7\%) and testicular (75.4\%) tissues. Also, PDC induced a significant elevation in renal MPO (327\%). Treatment of animals with CHI or CUR nanoparticles, for $5 \mathrm{~d}$ prior to PDC injection significantly retrieved the altered levels of all oxidative stress biomarkers (fig. 4). 

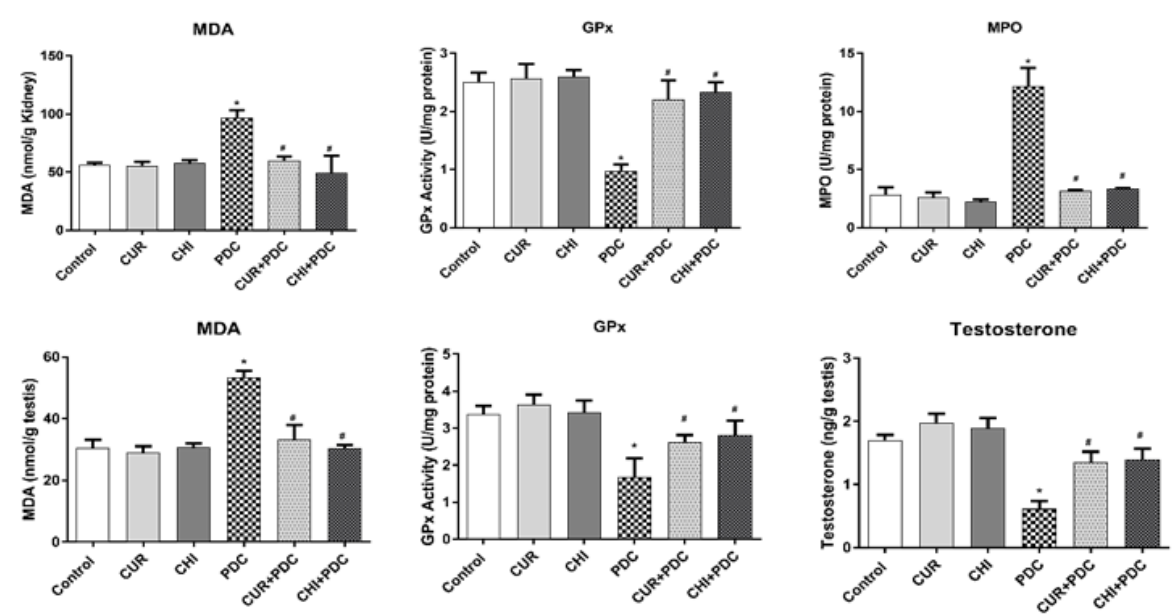

Fig. 4: Effects of nano CUR or nano CHI either alone or combined with PDC on the measured oxidative stress parameters [MDA level, GPX activity, and MPO activity] in the kidney of mice (upper raw), and the mice testicular MDA content, GPx activity, and testosterone level (lower raw). Data are expressed as mean $\pm S D$ based on data from independent experiments performed in triplicate. ${ }^{*} P \leq 0.05$ indicates statistical difference from the vehicle-treated (control) group, and $\# \mathbf{P} \leq 0.05$ indicates the statistical difference from the PDC-treated group in one-way ANOVA test with Tukey's multiple comparisons test

\section{Testicular testosterone}

Treatment with PDC significantly decreased testicular testosterone level by $64 \%$, while both the CHI and CUR nanoparticles individually did not show any significant change as compared to the control. Pretreatment with either CUR nanoparticles (Group V) or CHI nanoparticles (Group VI) ameliorated the testicular testosterone level significantly as compared to the PDC-treated group (fig. 4).

Western blot analysis of IL-18, IGF-1, caspase 3, and cytochrome c proteins

Administration of CUR or CHI nanoparticles showed no effect on the normal expression levels of the measured proteins in the renal and testicular tissues of mice. Induction of renal injury in mice with PDC increased the normal kidney contents of IL-18 (115\%), and IGF-1 (288\%) significantly. Also, the PDC significantly increased the normal testis contents of caspase 3 (190\%) and cytosolic cytochrome c (95\%). Pretreatment of mice with CUR or CHI nanoparticles significantly decreased PDC-induced elevation renal contents of IL-18 and IGF-1 and testicular contents of caspase 3, with no significant difference between the effects of both doses of CUR and CHI nanoparticles. There was also a decrease in cytosolic cytochrome c of pretreated (CUR+PDC and CHI+PDC) groups compared to the PDC-treated group but was not significant (fig. 5).

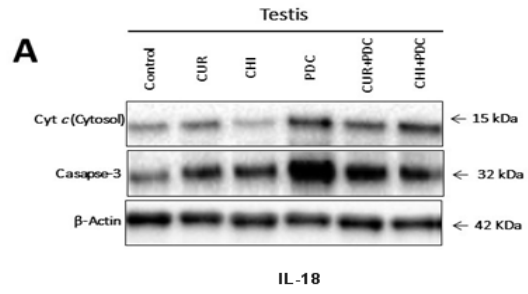

B
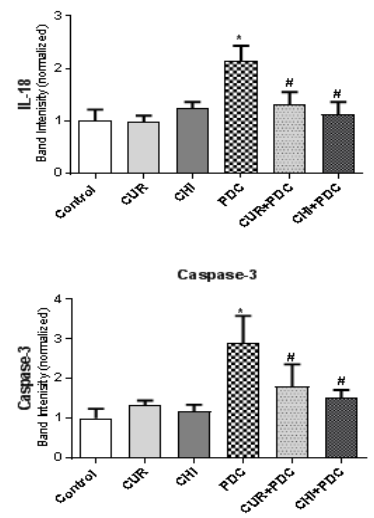
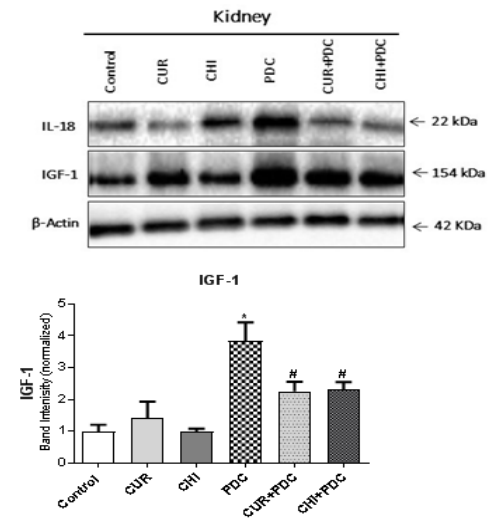

Cyt c

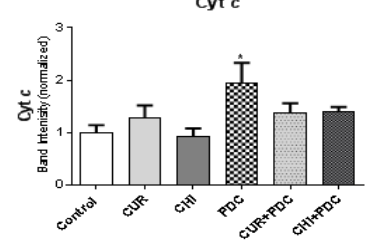

Fig. 5: Effects of nano CUR or nano CHI either alone or before PDC on testicular cytosolic cytochrome c (Cyt c) and caspase 3, and the renal interleukin-18 (IL-18) and insulin-like growth factor 1 (IGF-1) proteins. (A) Representative examples of a western blot images illustrating the cytosolic Cyt $c$ and caspase 3 in the testicular homogenate of mice (left), and IL-18 and IGF-1 protein levels in total lysates samples from the kidney of mice (right). (B) Quantification of Cyt $c$ and caspase 3 protein contents in the mice testis (upper), and IL-18 and IGF-1 protein levels in mice kidney (lower), with each normalized to the corresponding $\beta$-Actin bands. The specific protein of the control group is set to 1.0, and all band intensities are shown as mean $\pm \mathrm{SD}$ based on data from independent experiments performed in triplicate. ${ }^{*} \mathrm{P} \leq$ 0.05 indicates statistical difference from the vehicle-treated (control) group and $P \leq 0.05$ indicates statistical difference from the PDCtreated group in one-way ANOVA test with Tukey's multiple comparisons test 


\section{DISCUSSION}

In recent years, enormous researches have focused on using nanoparticles as carrier molecules to allow nano-drugs to reach the chosen targets with the most efficacy and minimum toxic effects. These particles due to its smaller size, can be transported easily to different body organs via blood circulation $[61,62]$. It was found that curcumin (CUR) nanoparticles possess more effectiveness than native CUR due to its particle size reduction [63]. Nano CUR has larger surface area so it may have a higher intracellular absorption capacity and higher systemic bioavailability in tissues compared to normal CUR [64]. Due to hydrophobic nature, CUR forming aggregates because of its low solubility in water; thus, CUR present inside the cytoplasm is very low while nano form dissolves completely in aqueous media, forming no aggregates due to the presence of zeta potential [65].

Chitosan (CHI) is affirmed as a nontoxic, biodegradable, and biocompatible compound according to FDA (Food and Drug Association) [66, 67]. Nano CHI have higher antimicrobial activities, antiviral, antifungal, antioxidant, and anti-inflammatory properties than CHI. Hence, nano CHI has the potential of becoming a powerful and safe natural promising candidate for therapeutic applications $[68,69]$. In the present study, administration of potassium dichromate (PDC) caused a significant decrease in the important antioxidant enzyme GPx in mouse kidney tissues, which function to protect cells from oxidative damage and overproduction of ROS [70]. The PDC toxicity induced also a significant increase of oxidative stress MDA, which indicates that the antioxidant defense system failed to inhibit the formation of free radicals and the enhancement of lipid peroxidation, which lead to kidney injury.

In addition, PDC induced a significant elevation in renal myeloperoxidase (MPO). Macrophages (neutrophils and monocytes) contain MPO, an enzyme that can cause tissue damage through formation of toxic reactive intermediates, such as hypochlorous acid ( $\mathrm{HOCl}$ ) out of hydrogen peroxide $\mathrm{H}_{2} \mathrm{O}_{2}$ when released extracellularly [71]. MPO is associated in the pathogenesis of kidney diseases because both MPO and its products ( $\mathrm{HOCl}$, tyrosyl radical, and reactive nitrogen intermediates) have been demonstrated in renal tissue diseases [72, 73]. Meanwhile, intracellularly, MPO plays a major role in killing microbes but is released extracellularly at inflammatory sites after phagocyte activation and causes damage to host tissues [71, 74].

On the other hand, pretreatment with nano CUR and nano CHI before PDC administration induced significant improvement in all biochemical parameters of the kidney. The results of Abd El-Rahman and Al-Jameel [50] declared that nano CUR is effective to protect against oxidative renal damage in male rats induced by cisplatin. Also, Ansar et al. [75] suggested that CUR nanoparticles exerted amelioration in the oxidative damage of renal tissue induced by lead in rats. The therapeutic effects of nano CUR are mediated through its antioxidant and anti-inflammatory properties. The study of AbdelWahhab et al. [76] suggested that CHI nanoparticles singly or plus quercetin suppress the oxidative stress and renal genotoxicity of rats fed ochratoxin A-contaminated diet.

Our results also showed that PDC induced a statistically significant increase in the percentage of total chromosomal aberrations in the bone marrow. Chromosome aberrations assay from bone marrow cells is a sensitive cytogenetic technique for testing of the mutagenic and carcinogenic effects of environmental contaminants [77]. $\mathrm{Cr}$ (VI), once penetrate cells, produces free radicals during reduction to the chromium metabolites $\mathrm{Cr}$ (V), $\mathrm{Cr}$ (IV) and $\mathrm{Cr}$ (III), which can subsequently attack DNA leading to several forms of genotoxicity such as strand breakage, gene mutation, DNA fragmentation, chromosomal aberration, and micronuclei formation [78-80]. This indicates that free radicals-induced oxidative damage to DNA, could be a factor in mediating the cytogenetic changes in bone marrow cells [81]. This conclusion is in agreement with Dana Devi et al:; Patlolla et al.; Patlolla et al. and Cengiz et al. [82-85], which showed a pronounced DNA damage of PDC with the comet assay.

Animals pretreated with nano CUR before PDC administration induced a significant improvement in chromosomal aberrations. The improving effect of nano CUR against PDC-induced cytogenetic toxicity may be attributed to its antioxidant activity, where CUR nanoparticles can lower ROS production, lipid peroxidation and augment the glutathione production [86, 87]. It also causes the production of 06-methylguanine-DNA methyltransferase, which is a protein required for cellular genome protection [88, 89]. Our results are in consent with those of Sankar et al. and Yadav et al. [81, 61]. Sankar et al. explored that nanoformulation of CUR have better protective effect than free CUR against arsenic-induced genotoxicity in bone marrow cells of rats including chromosomal aberrations, micronuclei formation and comet DNA damage. While Yadav et al. investigated the preventive potency of nano CUR in mitigating effects of arsenic and fluoride, which resulted in lowering of ROS and restoration of blood glutathione level altered by arsenic and fluoride.

The results also detected that mice pretreated with nano $\mathrm{CHI}$ exhibits significant protection against PDC induced chromosomal aberrations, likely through its free-radical scavenging activity, preventing oxidative stress and the DNA from damage. These findings are in agree with the previous results of Abdel-Wahhab et al. $[76,90]$. They found that CHI nanoparticles modulate GPx gene expression and prevent the genotoxicity of aflatoxin B1 in rat liver through decreasing liver genomic DNA fragmentation as well as MDA level. In addition, they revealed that CHI nanoparticles protect against the nephrotoxicity of ochratoxin and succeeded to mitigation these toxic effects through free radical scavenging properties, enhancement of the antioxidant capacity of quercetin, improvement in DNA fragmentation and improvement in GPx mRNA expression.

The present findings also demonstrated that the administration of PDC to mice resulted in a significant decline in the testicular testosterone levels and a decline in testicular antioxidant marker GPX, as well as a significant increase in the abnormal sperm morphology and a significant increase in testicular oxidative stress MDA which indicates that PDC is a male reproductive toxicant. These results were supported by the Oliveira et al. [91] who evaluated the effects of PDC on mouse sperm cells after short-term exposure. Their results showed an increase in the percentage of multiple abnormalities, a decrease in the percentage of normal spermatozoa, a decrease in spermatozoa motility, and a decrease in acrosome integrity. Furthermore, Bashandy et al. [92] found that PDC induced testicular lesions and alteration in testosterone level, which may lead to a spermatogenic arrest as appeared from reducing epididymal sperm number and increase of sperm abnormalities. The mechanism of reproductive deterioration by PDC might be associated with oxidative stress and disruption of the hypothalamic-pituitary-testicular feedback. Male germ cells and spermatozoa, because their membranes contain a high percentage of fatty acids, are more susceptible to oxidative stress than somatic cells. Oxidative stress considered a main agent in infertility, lead to sperm damage and deformity $[93,94]$.

On the other hand, our study showed that in the groups that pretreated with CUR or CHI nanoparticles before PDC, there was a significant reduction in the sperm abnormality and the testicular testosterone concentration was significantly raised and restored to its normal levels. The pretreatment with the two nanoparticles also significantly decreased MDA levels and increased the activity of GPX levels, owing to their potent antioxidant activity and free radical scavenger potential, which can decrease the lipid peroxidation (MDA level). The decrease in lipid peroxidation can increase the antioxidant defense system such as GPx, which protect against free radical attack and thus protect $\mathrm{PDC}$-induced testis damage. In agreement to our results, Ahmed-Farid et al. [95] showed that administration of CUR nano-encapsulation as a daily supplement improved the spermatogenesis defects induced by malnutritiontreated rats. Also, Sudjarwo et al. [96] found that CHI nanoparticle could protects rat testis from oxidative damage and apoptosis caused by lead acetate, through increasing antioxidants and inhibiting caspase 3 expression.

Induction of renal injury in mice by PDC in the present study resulted in a significant elevation in the expression of Interleukin-18 (IL-18) and insulin-like growth factor-1 (IGF-1) contents of the kidney. IL-18 is a pro-inflammatory cytokine that play an important role in renal injury and a potential mediator of tubular damage [97, 
98]. Also, the elevation of renal content of IGF-1 might contribute to the progression of PDC-induced chronic renal injury [99]. These results are in agree with those of Hegazy et al. [51], which revealed that PDC-induced acute nephrotoxicity and the involvement of IL-18 in the renal tissue damage and tubular injury induced by PDC. Moreover, IGF-1 also play an important role in the pathogenic renal tissue hypertrophy in PDC-acute nephrotoxicity. Pretreatment with CUR and CHI nanoparticles before PDC markedly decreased the renal contents of IL-18 and IGF-1 compared to the PDC-treated group. These observations documented that nanoparticles showed anti-inflammatory activity. That agrees with the previous findings that have confirmed that nanoparticles of CHI and CUR alone or in combination with hydroxyapatite nanoparticles significantly minimized the levels of inflammatory cytokines: TNF- $\alpha$ and IL- 6 in kidney tissues of male rats [100].

The PDC administration also significantly upregulated the testicular caspase-3 and cytosolic cytochrome c expressions at protein levels, compared to control animals which is indicative of spermatogenic cell apoptosis. The caspase- 3 activates cytoplasmic endonucleases that degrade the nuclear materials and proteins as well as cytoskeletal proteins [101, 102], which adversely impact spermatogenesis process. The mitochondrial dysfunction (increased the permeability of mitochondrial membrane) induced by oxidative stress can lead to the release of cytochrome $\mathrm{c}$ from mitochondria to the cytosol and then caspase activation, which results in apoptotic cell death [103].

On the other hand, CUR and CHI nanoparticles prior to PDC significantly decreased the upregulation of the testicular caspase- 3 induced by PDC. They also decreased the upregulation of the testicular cytochrome $\mathrm{c}$ but it was non-significant when compared to the PDC-treated group. This supports the anti-apoptotic action of nanoparticles in PDC-stimulated germ cell apoptosis. The anti-apoptotic action may involve regulation of pro-and anti-apoptotic proteins, the release of mitochondrial cytochrome c and activation of caspase-dependent cell death pathways. Taba et al. [104] showed that CUR administration causes a reduction in tunnel positive apoptotic cells as well as an alleviation in biochemical markers and sperm parameters in the testicular tissue of the aging mouse model. Furthermore, the investigation of Zalok et al. [105] showed that co-administration of CHI nanoparticles with cimetidine resulted in the weak immune response against caspase 3 in the seminiferous tubules of mouse testicular tissues.

\section{CONCLUSION}

Potassium dichromate resulted significantly in cytotoxic and cytogenetic effects as indicated by changes in the biochemical parameters, protein expression of kidney and testis, structure and number of chromosomes and sperm morphology in mice. Protection with nanoparticles of curcumin and chitosan are significantly able to alleviate these toxic effects through by enhancement of antioxidant capacity, reduction of oxidative stress, chromosomal aberrations and sperm abnormalities as well as regulation of expression of inflammatory cytokines and apoptotic proteins. Moreover, chitosan nanoparticles were found significantly more effective than curcumin nanoparticles in reducing chromosomal aberrations and sperm abnormalities induced by potassium dichromate.

\section{FUNDING}

Nil

\section{AUTHORS CONTRIBUTIONS}

All authors have contributed equally.

\section{CONFLICTS OF INTERESTS}

All authors have none to declare.

\section{REFERENCES}

1. Tchounwou PB, Yedjou CG, Patlolla AK, Sutton DJ. Heavy metal toxicity and the environment. Exp Suppl 2012;101:133-64.

2. Al Osman M, Yang F, Massey IY. Exposure routes and health effects of heavy metals on children. Biometals 2019;32:563-73.
3. Rahman $Z$, Singh VP. The relative impact of toxic heavy metals (THMs) (arsenic (As), cadmium (Cd), chromium (Cr)(VI), mercury $(\mathrm{Hg})$, and lead $(\mathrm{Pb})$ ) on the total environment: an overview. Environ Monit Assess 2019;419:1-21.

4. Pavesi T, Moreira JC. Mechanisms and individuality in chromium toxicity in humans. J Appl Toxicol 2020;40:1183-97.

5. Chen H, Arocena JM, Li J, Thring RW, Zhou J. Mobility and storage sinks for chromium and other metals in soils impacted by leather tannery wastes. J Environ Monit 2012;14:3240-8.

6. Jaishankar M, Tseten T, Anbalagan N, Mathew BB, Beeregowda KN. Toxicity, mechanism and health effects of some heavy metals. Interdiscip Toxicol 2014;7:60-72.

7. Matern K, Mansfeldt T. Chromium release from a COPRcontaminated soil at varying water content and redox conditions. J Environ Qual 2016;45:1259-67.

8. Avila Rojas SH, Tapia E, Briones Herrera A, Aparicio Trejo OE, Leon Contreras JC, Hernandez Pando $\mathrm{R}$, et al. Curcumin prevents potassium dichromate (K2Cr207)-induced renal hypoxia. Food Chem Toxicol 2018;121:472-82.

9. Mary Momo CM, Ferdinand N, Omer Bebe NK, Alexane Marquise MN, Augustave $\mathrm{K}$, Bertin Narcisse V, et al. Oxidative effects of potassium dichromate on biochemical, hematological characteristics, and hormonal levels in rabbit doe (Oryctolagus cuniculus). Vet Sci 2019;6:1-13.

10. Rasool M, Zaigham K, Malik A, Naseer MI, Umm-E-Habiba, Manan A, et al. Potential reproductive health effects and oxidative stress associated with exposure to potassium dichromate (K2Cr2O7) and magnesium sulphate (MgSO4) in male mice. Pak J Med Sci 2014;30:819-23.

11. Marouani N, Tebourbi O, Hallegue D, Mokni M, Yacoubi MT, Sakly M, et al. Mechanisms of chromium hexavalent-induced apoptosis in rat testes. Toxicol Ind Health 2017;33:97-106.

12. Yoisungnern T, Das J, Choi YJ, Parnpai R, Kim JH. Effect of hexavalent chromium-treated sperm on in vitro fertilization and embryo development. Toxicol Ind Health 2016;32:1700-10.

13. Mamyrbaev AA, Dzharkenov TA, Imangazina ZA, Satybaldieva UA. Mutagenic and carcinogenic actions of chromium and its compounds. Environ Health Prev Med 2015;20:159-67.

14. Subramanian S, Rajendiran G, Sekhar P, Gowri C, Govindarajulu P, Aruldhas MM. Reproductive toxicity of chromium in adult bonnet monkeys (Macaca radiata geoffrey). Reversible oxidative stress in the semen. Toxicol Appl Pharmacol 2006;215:237-49.

15. Bosgelmez II, Guvendik G. N-Acetyl-L-Cysteine protects liver and kidney against chromium(vi)-induced oxidative stress in mice. Biol Trace Elem Res 2017;178:44-53.

16. Abu Zeid EH, Hussein MMA, Ali H. Ascorbic acid protects male rat brain from oral potassium dichromate-induced oxdative DNA damage and apoptotic changes: the expression patterns of caspase-3, P 53, Bax, and Bcl-2 genes. Environ Sci Pollut Res Int 2018;25:13056-66.

17. Li J, Zheng X, Ma X, Xu X, Du Y, Lv Q, et al. Melatonin protects against chromium(VI)-induced cardiac injury via activating the AMPK/Nrf2 pathway. J Inorg Biochem 2019;197:110698.

18. Dashti A, Soodi M, Amani N. Cr (VI) induced oxidative stress and toxicity in cultured cerebellar granule neurons at different stages of development and protective effect of rosmarinic acid. Environ Toxicol 2016;31:269-77.

19. Luo D, Xu Z, Hu X, Zhang F, Bian H, Li N, et al. URI prevents potassium dichromate-induced oxidative stress and cell death in gastric cancer cells. Am J Transl Res 2016;8:5399-409.

20. Mohamed HM, Abd El-Twab SM. Gallic acid attenuates chromium-induced thyroid dysfunction by modulating antioxidant status and inflammatory cytokines. Environ Toxicol Pharmacol 2016;48:225-36.

21. Xueting L, Rehman MU, Mehmood K, Huang S, Tian X, Wu X, et al. Ameliorative effects of nano-elemental selenium against hexavalent chromium-induced apoptosis in broiler liver. Environ Sci Pollut Res Int 2018;25:15609-15.

22. Wu YH, Lin JC, Wang TY, Lin TJ, Yen MC, Liu YH, et al. Hexavalent chromium intoxication induces intrinsic and extrinsic apoptosis in human renal cells. Mol Med Rep 2020;21:851-7.

23. Kumar P, Kumar R, Nagpure NS, Nautiyal P, Kushwaha B, Dabas A. Genotoxicity and antioxidant enzyme activity induced by 
hexavalent chromium in Cyprinus carpio after in vivo exposure. Drug Chem Toxicol 2013;36:451-60.

24. Rocha C, Cardoso P, Cunha L, Gomes C, Junior RR, Pinheiro RH, et al. Mutagenic effects of potassium dichromate as evaluated by means of animal and plant bioindicators. In Vivo 2015;29:729-35.

25. El-Demerdash FM, Jebur AB, Nasr HM, Hamid HM. Modulatory effect of Turnera diffusa against testicular toxicity induced by fenitrothion and/or hexavalent chromium in rats. Environ Toxicol 2019;34:330-9.

26. Hfaiedh M, Brahmi D, Zourgui MN, Zourgui L. Phytochemical analysis and nephroprotective effect of cactus (Opuntia ficusindica) cladodes on sodium dichromate-induced kidney injury in rats. Appl Physiol Nutr Metab 2019;44:239-47.

27. Amalraj A, Pius A, Gopi S, Gopi S. Biological activities of curcuminoids, other biomolecules from turmeric and their derivatives-a review. J Tradit Complement Med 2017;7:205-33.

28. Kocaadam B, Sanlier N. Curcumin, an active component of turmeric (Curcuma longa), and its effects on health. Crit Rev Food Sci Nutr 2017;57:2889-95.

29. El-Maddawy ZK, El-Sayed YS. Comparative analysis of the protective effects of curcumin and $\mathrm{N}$-acetyl cysteine against paracetamol-induced hepatic, renal, and testicular toxicity in Wistar rats. Environ Sci Pollut Res Int 2018;25:3468-79.

30. Cao L, Zhi D, Han J, Kumar Sah S, Xie Y. Combinational effect of curcumin and metformin against gentamicin-induced nephrotoxicity: involvement of antioxidative, anti-inflammatory and antiapoptotic pathway. J Food Biochem 2019;43:1-9.

31. Aslanturk A, Uzunhisarcikli M. Protective potential of curcumin or taurine on nephrotoxicity caused by bisphenol A. Environ Sci Pollut Res Int 2020;27:23994-4003.

32. Zhang J, Tang L, Li G Sen, Wang J. The anti-inflammatory effects of curcumin on renal ischemia-reperfusion injury in rats. Ren Fail 2018;40:680-6.

33. Samarghandian S, Azimi Nezhad M, Farkhondeh T, Samini F. Anti-oxidative effects of curcumin on immobilization-induced oxidative stress in rat brain, liver and kidney. Biomed Pharmacother 2017;87:223-9.

34. Belhan S, Yildirim S, Huyut Z, Ozdek U, Oto G, Algul S. Effects of curcumin on sperm quality, lipid profile, antioxidant activity and histopathological changes in streptozotocin-induced diabetes in rats. Andrologia 2020;52:1-8.

35. Tomeh MA, Hadianamrei R, Zhao X. A review of curcumin and its derivatives as anticancer agents. Int J Mol Sci 2019;27;20:1-26.

36. Pan MH, Huang TM, Lin JK. Biotransformation of curcumin through reduction and glucuronidation in mice. Drug Metab Dispos 1999;27:486-94.

37. Anand P, Kunnumakkara AB, Newman RA, Aggarwal BB. Bioavailability of curcumin: problems and promises. Mol Pharm 2007;4:807-18.

38. Dei Cas M, Ghidoni R. Dietary curcumin: correlation between bioavailability and health potential. Nutrients 2019;11:1-14.

39. Das RK, Kasoju N, Bora U. Encapsulation of curcumin in alginate-chitosan-pluronic composite nanoparticles for delivery to cancer cells. Nanomedicine 2010;6:153-60.

40. Gera M, Sharma N, Ghosh M, Huynh DL, Lee SJ, Min T, et al. Nanoformulations of curcumin: an emerging paradigm for improved remedial application. Oncotarget 2017;8:66680-98.

41. Hadidi M, Pouramin S, Adinepour F, Haghani S, Jafari SM. Chitosan nanoparticles loaded with clove essential oil: characterization, antioxidant and antibacterial activities. Carbohyd Polym 2020;236:116075.

42. Kravanja G, Primozic M, Knez Z, Leitgeb M. Chitosan-based (nano)materials for novel biomedical applications. Molecules 2019;24:1-23.

43. Bai K, Hong B, He J, Huang W. Antioxidant capacity and hepatoprotective role of chitosan-stabilized selenium nanoparticles in concanavalin a-induced liver injury in mice. Nutrients 2020;12;1-16.

44. Darwesh OM, Sultan YY, Seif MM, Marrez DA. Bio-evaluation of crustacean and fungal nano-chitosan for applying as a food ingredient. Toxicol Rep 2018;5:348-56.

45. Elchinger PH, Delattre C, Faure S, Roy O, Badel S, Bernardi T, et al. Antioxidant activities of peptoid-grafted chitosan films. Appl Biochem Biotechnol 2017;181:283-93.
46. Ivanova DG, Yaneva ZL. Antioxidant properties and redoxmodulating activity of chitosan and its derivatives: biomaterials with application in cancer therapy. BioRes Open Access 2020;9:64-72.

47. Chang SH, Wu CH, Tsai GJ. Effects of chitosan molecular weight on its antioxidant and antimutagenic properties. Carbohyd Polym 2018;181:1026-32.

48. Lee DW, Shirley SA, Lockey RF, Mohapatra SS. Thiolated chitosan nanoparticles enhance anti-inflammatory effects of intranasally delivered theophylline. Respir Res 2006;7:1-10.

49. Dragostin OM, Tatia R, Samal SK, Oancea A, Zamfir AS, Dragostin I, et al. Designing of chitosan derivatives nanoparticles with antiangiogenic effect for cancer therapy. Nanomaterials 2020;10:1-19.

50. Abd El-Rahman SN, Al-Jameel SS. Protection of curcumin and curcumin nanoparticles against cisplatin induced nephrotoxicity in male rats. SAJB 2014;2:214-23.

51. Hegazy R, Salama A, Mansour D, Hassan A. Renoprotective effect of lactoferrin against chromium-induced acute kidney injury in rats: involvement of il-18 and igf-1 inhibition. PLoS One 2016;11:1-18.

52. Preston RJ, Dean BJ, Galloway S, Holden H, McFee AF, Shelby M. Mammalian in vivo cytogenetic assays. Analysis of chromosome aberrations in bone marrow cells. Mutat Res 1987;189:157-65.

53. Wyrobek AJ, Bruce WR. Chemical induction of sperm abnormalities in mice. Proc Natl Acad Sci USA 1975;72:4425-9.

54. Bradford MM. A rapid and sensitive method for the quantitation of microgram quantities of protein utilizing the principle of protein-dye binding. Anal Biochem 1976;72:248-54.

55. Guo CH, Huang CJ, Chen ST, Wang Hsu GS. Serum and testicular testosterone and nitric oxide products in aluminum-treated mice. Environ Toxicol Pharmacol 2001;10:53-60.

56. Mihara M, Uchiyama M. Determination of malonaldehyde precursor in tissues by thiobarbituric acid test. Anal Biochem 1978;86:271-8.

57. Paglia DE, Valentine WN. Studies on the quantitative and qualitative characterization of erythrocyte glutathione peroxidase. J Lab Clin Med 1967;70:158-69.

58. Hillegass LM, Griswold DE, Brickson B, Albrightson Winslow C. Assessment of myeloperoxidase activity in whole rat kidney. J Pharmacol Methods 1990;24:285-95.

59. Burnette WN. "Western blotting": electrophoretic transfer of proteins from sodium dodecyl sulfate-polyacrylamide gels to unmodified nitrocellulose and radiographic detection with antibody and radioiodinated protein A. Anal Biochem 1981;112:195-203.

60. Sambrook J, Fritsch EF, Maniatis T. Textbook of molecular cloning: a laboratory manual. 2nd Ed. Cold Spring Harbor Laboratory Press: Cold Spring Harbor, NY USA; 1989.

61. Yadav A, Kushwaha P, Flora SJS. Nanocurcumin prevents oxidative stress-induced following arsenic and fluoride coexposure in rats. Def Life Sci J 2016;1:69-77.

62. Elmi T, Esboei BR, Sadeghi F, Zamani Z, Didehdar M, Fakhar M, et al. In vitro antiprotozoal effects of nano-chitosan on Plasmodium falciparum,Ggiardia lamblia and Trichomonas vaginalis. Acta Parasitol 2020. https://doi.org/10.1007/ s11686-020-00255-6.

63. Flora G, Gupta D, Tiwari A. Nanocurcumin: a promising therapeutic advancement over native curcumin. Crit Rev Ther Drug 2013;30:331-68.

64. Zou P, Zhang J, Xia Y, Kanchana K, Guo G, Chen W, et al. ROS generation mediates the anti-cancer effects of WZ35 via activating JNK and ER stress apoptotic pathways in gastric cancer. Oncotarget 2015;6:5860-76.

65. Karthikeyan A, Senthil N, Min T. Nanocurcumin: a promising candidate for therapeutic applications. Front Pharmacol 2020;11:1-24

66. Bernkop Schnürch A, Dünnhaupt S. Chitosan-based drug delivery systems. Eur J Pharm Biopharm 2012;81:463-9.

67. Maftoonazad N, Badii F, Shahamirian M. Recent innovations in the area of edible films and coatings. Recent Pat Food Nutr Agric 2013;5:201-13.

68. Maluin FN, Hussein MZ. Chitosan-based agronanochemicals as a sustainable alternative in crop protection. Molecules 2020;25:1-22. 
69. Phuong Ngo TM, Nguyen TH, Quyen Dang TM, Tran TX, Rachtanapun P. Characteristics and antimicrobial properties of active edible films based on pectin and nanochitosan. Int J Mol Sci 2020;21:1-16.

70. Owolabi JO, Ghazal OK, Williams FE, Ayodele EO. Effect of Moringa oleifera (drumstick) leaf extracts on lead-induced testicular toxicity in adult wistar rat (Rattus novergicus). Int J Biotechnol Biomed Res 2012;2:4003-9.

71. Klebanoff S. Myeloperoxidase: friend and foe. J leukoc Biol 2005;77:1-28.

72. Malle E, Woenckhaus C, Waeg G, Esterbauer H, Grone E, Grone $\mathrm{H}$. Immunological evidence for hypochlorite-modified proteins in human kidney. Am J Pathol 1997;150:603-15.

73. Grone HJ, Grone E, Malle E. Immunohistochemical detection of hypochlorite-modified proteins in glomeruli of human membranous glomerulonephritis. Lab Invest 2002;82:5-14.

74. Odobasic D, Kitching AR, Semple TJ, Holdsworth SR. Endogenous myeloperoxidase promotes neutrophil-mediated renal injury, but attenuates $t$ cell immunity inducing crescentic glomerulonephritis. J Am Soc Nephrol 2007;18:760-70.

75. Ansar S, Farhat S, Albati AAM, Abudawood M, Hamed S. Effect of curcumin and curcumin nanoparticles against lead-induced nephrotoxicity. Biomed Res 2019;30:57-60.

76. Abdel Wahhab MA, Aljawish A, El-Nekeety AA, Abdel-Aziem SH, Hassan NS. Chitosan nanoparticles plus quercetin suppress the oxidative stress, modulate DNA fragmentation and gene expression in the kidney of rats fed ochratoxin A-contaminated diet. Food Chem Toxicol 2017;99:209-21.

77. Karabay NU, Oguz MG. Cytogenetic genotoxic effects of the insecticides, imidacloprid methamidophos. Genet Mol Res 2005;4:653-62.

78. Itoh S, Shimada H. Micronucleus induction by chromium and selenium, and suppression by metallothionein inducer. Mutat Res 1996;367:233-6.

79. Wang XF, Xing ML, Shen Y, Zhu X, Xu LH. Oral administration of Cr (VI) induced oxidative stress, DNA damage and apoptotic cell death in mice. Toxicology 2006;228:16-23.

80. Wise SS, Holmes AL, Wise SR. Hexavalent chromium-induced DNA damage and repair mechanisms. Rev Environ Health 2008;23:39-57

81. Sankar P, Telang AG, Ramya K, Vijayakaran K, Kesavan M, Sarkar SN. Protective action of curcumin and nano-curcumin against arsenic-induced genotoxicity in rats in vivo. Mole Biol Rep 2014;41:7413-22.

82. Dana Devi K, Rozati R, Saleha Banu B, Jamil K, Grover P. In vivo genotoxic effect of potassium dichromate in mice leukocytes using the comet assay. Food Chem Toxicol 2001;39:859-65.

83. Patlolla AK, Barnes C, Yedjou C, Velma VR, Tchounwou PB. Oxidative stress, DNA damage, and antioxidant enzyme activity induced by hexavalent chromium in sprague-dawley rats. Environ Toxicol 2009a;24:66-73.

84. Patlolla AK, Barnes C, Hackett D, Tchounwou PB. Potassium dichromate induced cytotoxicity, genotoxicity and oxidative stress in human liver carcinoma (HepG2) cells. Int J Environ Res Public Health 2009b;6:643-53.

85. Cengiz M, Alansal NO, Tuncdemir M, Tanriverdi G, Bayoglu B. Evaluation of effects of melatonin and caffeic acid phenethyl ester on acute potassium dichromate toxicity and genotoxicity in rats. Indian J Pharmacol 2016;48:407-11.

86. Sankar P, Telang AG, Kalaivanan R, Vijayakaran K, Kesavan M, Sarkar SN. Effects of nanoparticle-encapsulated curcumin on arsenic-induced liver toxicity in rats. Environ Toxicol 2013b;30:628-37.

87. Sankar P, Telang AG, Kalaivanan R, Vijayakaran K, Kesavan M, Suresh $\mathrm{S}$, et al. Oral nanoparticulate curcumin combating arsenic-induced oxidative damage in kidney and brain of rats. Toxicol Ind Health 2016;32:410-21.
88. Rajeswari A. Curcumin protects mouse brain from oxidative stress caused by 1-methyl-4-phenyl-1,2,3,6-tetrahydropyridine. Eur Rev Med Pharmacol Sci 2006;10:157-61.

89. Niture SK, Velu CS, Smith QR, Bhat GJ, Srivenugopal KS. Increased expression of the MGMT repair protein mediated by cysteine prodrugs chemopreventative natural products in human lymphocytes tumor cell lines. Carcinogenesis 2007;28:378-89.

90. Abdel Wahhab MA, Aljawish A, El-Nekeety AA, Abdel Aiezm $\mathrm{SH}$, Abdel Kader HAM, Rihn BH, et al. Chitosan nanoparticles and quercetin modulate gene expression and prevent the genotoxicity of aflatoxin B1in rat liver. Toxicol Rep 2015;2:737-47.

91. Oliveira H, Spano M, Guevara MA, Santos TM, Santos C, Pereira ML. Evaluation of in vivo reproductive toxicity of potassium chromate in male mice. Exp Toxicol Pathol 2010;62:391-404.

92. Bashandy SA, Ahmed Farid OA, Omara EA, El-Toumy SA, Salib JY. Protective effect of Citrus reticulata peel extract against potassium dichromate-induced reproductive toxicity in rats. Asian Pac J Reprod 2019;8:267-75.

93. Sanocka D, Kurpisz M. Reactive oxygen species and sperm cells. Reprod Biol Endocrinol 2004;2:1-7.

94. Acharya UR, Mishra M, Patro J, Panda MK. Effect of vitamins C and $\mathrm{E}$ on spermatogenesis in mice exposed to cadmium. Reprod Toxicol 2008;25:84-8

95. Ahmed Farid OAH, Nasr M, Ahmed RF, Bakeer RM. Beneficial effects of curcumin nano-emulsion on spermatogenesis andreproductive performance in male rats under proteindeficient diet model: enhancement of sperm motility, conservancy of testicular tissue integrity, cell energy and seminal plasma amino acids content. J Biomed Sci 2017;24:1-14

96. Sudjarwo SA, Anwar C, Wardani G, Eraiko K, Koerniasari. Antioxidant and anti-caspase 3 effect of chitosan-Pinus merkusii extract nanoparticle against lead acetate-induced testicular toxicity in rat. Asian Pac J Reprod 2019;8:13-9.

97. Melnikov VY, Ecder T, Fantuzzi G, Siegmund B, Lucia MS, Dinarello CA, et al. Impaired IL-18 processing protects caspase1-deficient mice from ischemic acute renal failure. J Clin Invest 2001;107:1145-52.

98. Wu H, Craft ML, Wang P, Wyburn KR, Chen G, Ma J, et al. IL-18 contributes to renal damage after ischemia-reperfusion. J Am Soc Nephrol 2008;19:2331-41.

99. Oh Y. The insulin-like growth factor system in chronic kidney disease: Pathophysiology and therapeutic opportunities. Kidney Res Clin Pract 2012;31:26-37.

100. Mosa IF, Youssef M, Kamel M, Mosa OF, Helmy Y. Synergistic antioxidant capacity of CsNPs and CurNPs against cytotoxicity, genotoxicity and pro-inflammatory mediators induced by hydroxyapatite nanoparticles in male rats. Toxicol Res 2019;8:939-52.

101. Huang Y, Nakada S, Ishiko T, Utsugisawa T, Datta R, Kharbanda $\mathrm{S}$, et al. Role for caspase-mediated cleavage of Rad51 in induction of apoptosis by DNA damage. Mol Cell Biol 1999;4:2986-97.

102. Mcllwain DR, Berger T, Mak TW. Caspase functions in cell death and disease. Cold Spring Harb Perspect Biol 2013;5:1-28.

103. Leon J, Acuna Castroviejo D, Escames G, Tan DX. Melatonin mitigates mitochondrial malfunction. J Pineal Res 2005;38:1-9.

104. Taba MY, Mohammadi S, Jalali M, Farimah Beheshti F, Attari SS. Effects of different doses of curcumin on testicular histopathology, apoptosis, and reproductive organs weight index in mice D-galactose-induced aging model. Comp Clin Pathol 2019;28:997-1002.

105. Zalok FM, Madbouly SM, Abdouh ES, Elnagar DM. The potent role of smart chitosan nanoparticles on the attenuation of testicular damage cimetidin-induced in swiss albino mice. EJBPS 2019;6:115-20. 